FLUID POWER LOGIC CIRCUIT DESIGN 


\section{Titles of Related Interest}

A. B. Goodwin: Fluid Power Systems theory, worked examples and problems

J. D. Stringer: Hydraulic Systems Analysis 


\title{
FLUID POWER LOGIC CIRCUIT DESIGN
}

\section{ANALYSIS, DESIGN METHODS} and WORKED EXAMPLES

\author{
Peter Rohner
}

Royal Melbourne Institute of Technology 
() Peter Rohner 1979

Softcover reprint of the hardcover 1st edition 1979

All rights reserved. No part of this publication may be reproduced or transmitted, in any form or by any means, without permission.

First published 1979 by

THE MACMILLAN PRESS LTD

London and Basingstoke

Associated companies in Delhi Dublin Hong Kong Johannesburg Lagos Melbourne

New York Singapore and Tokyo

Typeset IBM Press Roman by

Reproduction Drawings Ltd.

Sutton, Surrey

British Library Cataloguing in Publication Data

Rohner, Peter

Fluid power logic circuit design

1. Fluid devices

2. Logic design

I. Title

$629.8^{\prime} 313 \quad$ TJ853

ISBN 978-0-333-25647-3 ISBN 978-1-349-16126-3 (eBook)

DOI 10.1007/978-1-349-16126-3

This book is sold subject to the standard conditions of the

Net Book Agreement.

The paperback edition of this book is sold subject to the condition that it shall not, by way of trade or otherwise, be lent, resold, hired out, or otherwise circulated without the publisher's prior consent in any form of binding or cover other than that in which it is published and without a similar condition including this condition being imposed on the subsequent purchaser. 


\section{Contents}

Preface

vi

\section{PART I}

1. Pneumatic Symbols and Control Element Description 1

2. Position-sensing and Pressure-sensing 18

3. Circuit Layout, Presentation and Labelling 21

4. Control Problem Analysis 26

5. Fringe Condition Modules and their Integration 28

PART II

6. Design Method Considerations for Sequential Circuits

7. Sequential Logic Circuit Design with Karnaugh-Veitch Mapping Method

8. Compound Circuit Design

9. Circuit Design with Step-counter Method

PART III

10. Combinational Circuit Design

11. Pneumatic Counters

12. Mixed Control Circuit Design 


\section{PART IV}

13. Pneumatic Control for Hydraulic Sequential Power Systems

Solutions to Problems

203

Index

22 


\section{Preface}

Pneumatic control lends itself ideally to a vast variety of low-cost industrial automation applications and has been proven on many simple, as well as complex, machines. The binary character of most fluid power control valves enables them to be used in the same way as electronic components. It therefore follows that fluid power circuit designers should use the same design methods that have been used over the past two decades and are still used by electronic circuit designers. Logically constructed control circuits have numerous advantages over intuitively designed circuits and always lead to an optimal solution.

In order to provide a teaching aid suitable for machine designers and technicians, this book avoids using the specialised terminology often found in electronics textbooks. Also, more than 250 illustrations, circuits and charts are included in order to facilitate learning and understanding. In addition, some 35 industrial control problems of a sequential and combinational nature, for both pneumatics and hydraulics, are discussed in detail and solved.

The book is divided into four main parts: Part I familiarises the reader with fluid power components, circuit presentation methods and ancillary circuitry in modular form. Part II provides a step-by-step introduction to sequential logic circuit design, utilising the well-known Karnaugh-Veitch map for signal-flow presentation and equation minimisation; step-counter circuit design is also extensively discussed and illustrated. Part III provides insight into the mystery of combinational circuit design and the Karnaugh-Veitch map is again used, together with truth tables for circuit optimisation and problem analysis. Binary counting principles are applied to fluid power circuits in Part IV and a number of practical control problems utilising binary counters are provided. In this book Boolean algebra is confined to its use for obtaining switching expressions. There are, of course, numerous textbooks that expound the general theory of Boolean algebra and related methods, such as the Quine-McCluskey method, in much greater depth.

As a teacher, I have written this book with the needs of students in mind. Its internal structure as well as its content should provide sufficient basic theory and application for technician, higher technician and degree-level courses. 
I should like to express my thanks to my colleague, Norman Walkadine, whose help was of great value. I should further like to thank the Royal Melbourne Institute of Technology for providing facilities which made this book possible. Last, but not least, I should like to thank my dear wife Heidi and my children Rahel and Michael who provided invaluable moral support while I was writing this book.

PETER ROHNER 